\title{
Is the Role of Urban Planning in Promoting Active Ageing Fully Understood? A Comparative Review of International Initiatives to Develop Age-Friendly Urban Environments
}

Jordi Bosch-Meda

Received: 2021-01-29 | Final version: 2021-05-21

\begin{abstract}
After reviewing the related literature on age-friendly urban environments, the theoretical backgrounds about the relationship between ageing and built environment and the age-friendly urban planning theories, and analysing the six main international initiatives to promote age-friendly environments through the qualitative document analysis (QDA) method, the article argues that urban planning remains at the margins of the interdisciplinary discourse on ageing and environment. There is, however, a broad consensus on the usefulness of certain age-friendly urban planning features: compactness, density, and diversity. The origins of these general criteria are multiple. At the theoretical level, they are the result of the on-going development of the 'ageing in place' concept but they also come from urban planning theory itself, in particular, from multigenerational planning, which is based on smart growth premises. Beyond these general urban planning criteria, some specific planning instruments can decisively contribute to develop a more comprehensive age-friendly urban planning approach such as inclusionary zoning or Transit-Oriented Development. Nonetheless, there is a notable gap between theoretical framework and its implementation. Urban planning plays a minor role in many of the international initiatives to promote age-friendly environments. It could be concluded that there is neither a comprehensive approach to the potential of urban planning nor any development or in-depth analysis of an age-friendly urban planning model in the most relevant international programmes.
\end{abstract}

Keywords: City planning; multigenerational planning; older people; active ageing

Citation

\section{¿Se comprende el papel de la planificación urbana en el fomento del envejecimiento activo? Una revisión comparada de las iniciativas internacionales para entornos age-friendly}

Resumen

\begin{abstract}
Después de revisar la literatura sobre entornos urbanos age-friendly, sus antecedentes teóricos, y las teorías de planificación relacionadas, y analizar las seis principales iniciativas internacionales sobre esta cuestión a través del análisis cualitativo de documentos (QDA), el artículo sostiene que el urbanismo se mantiene al margen del discurso interdisciplinario sobre envejecimiento y entorno. No obstante, existe un amplio consenso sobre la necesidad de ciertas características para una planificación urbana age-friendly: compacidad, densidad y diversidad. Los orígenes de estos criterios generales son múltiples. A nivel teórico, son el resultado del desarrollo continuo del concepto de "envejer en el lugar", pero también provienen de la propia teoría de la planificación urbana, en particular, de la planificación multigeneracional, que se basa en premisas de crecimiento inteligente. Más allá de estos criterios generales, algunos instrumentos de planificación específicos pueden contribuir decisivamente a desarrollar un enfoque más integral con la vejez, como la zonificación inclusiva o el desarrollo orientado al tránsito. Sin embargo, existe una brecha notable entre el marco teórico y su implementación. La planificación urbana juega un papel menor en muchas de estas iniciativas internacionales. Se podría concluir que no existe un enfoque integral del potencial de la planificación urbana ni ningún desarrollo o análisis en profundidad de un modelo de planificación urbana amigable con las personas mayores en los programas internacionales más relevantes.
\end{abstract}

Palabras clave: Planificación urbana; urbanismo multigeneracional; personas mayores; envejecimiento activo

1 Ph.D. Architect, Assistant Professor, Universitat Politècnica de Catalunya (ORCiD: 0000-0001-7678-0953, Scopus Author ID: 57189711954, WoS ResearcherID: 


\section{Introduction}

Active ageing is a concept developed by the World Health Organisation (WHO) It has been defined as "... the process of optimizing opportunities for health, participation and security in order to enhance quality of life as people age" (WHO, 2002, p. 12). According to WHO, elements that determine active ageing may be classified into six groups: economic factors, social factors, behavioural factors, personal factors, health and social services, and the physical environment.

In view of these factors, urban planning should play a key role in promoting active ageing. Urban planning, also referred to as city planning or town planning, is a multidimensional discipline whose goal is to plan and design the establishment, growth and renewal of urban environments at physical, social and economic levels to offer the best quality of life and well-being to all citizens. Given that cities are complex systems (Batty, 2008) urban planning decisions have a wide reach, controlling land use, location of services, public facilities, and green areas, defining patterns of growth, landscape architecture, urban design, infrastructure planning. They also determine mobility options, transportation systems and behavioural factors which are also critical to active ageing. Consequently, urban planning, as the means of organizing all elements of urban environment, is the foundation on which all sectoral policies in fields such as housing, mobility and transportation, green areas, social services or public health should be articulated, coordinated and integrated. In this context, the aim of the article is to examine to what extent the role of urban planning has been considered in major international initiatives to promote age-friendly cities.

The structure of the paper is as follows. Based on a brief literature review (a comprehensive literature review is beyond the scope of this article), the first section highlights how built environments are inadequate for the changing needs of older people. The second analyses the theoretical frameworks that underpin age-friendly urban planning. The third discusses the attributes that age-friendly urban planning should have. The fourth evaluates the role of urban planning in the most relevant international age-friendly programmes. The concluding section summarises the findings.

\section{The built environment and the changing needs of older people}

Much research highlights the frequent inadequacy of urban environments to meet the needs of older people, limiting their ability to live independently, and compromising their wellbeing (e.g. Kellaher et al., 2004; Abbott, \& Sapsford, 2005; HM Government, 2006; Weil, \& Smith, 2016). All these obstacles can be divided into two broad interrelated domains: the physical and the social environment (e.g. Lui et al., 2009; Menec et al., 2011; Steels, 2015; Menec, \& Brown, 2018).

Regarding the physical environment, research on age-friendly communities (e.g. Michael et al., 2006; Alley et al., 2007; Glicksman, \& Ring, 2017) and international policy programmes (see Table 1) have emphasized the importance of four areas: housing, public transport and mobility, public spaces and green areas, and the availability and accessibility of public facilities and services.

Housing is a critical element. Human health, well-being and quality of life are profoundly affected by housing conditions. There is a large body of evidence linking inadequate housing conditions with adverse effects on physical and mental health, and mortality (e.g. Harrison, \& Heywood, 2000; Thompson et al., 2002; Evans et al., 2003; Heywood 2004; Mehdipanah et al., 2019). For older people, the impact of housing on health and well-being is amplified. As ageing leads to a higher likelihood of physical, cognitive, and sensory impairments, the concept of 'housing adequacy' varies 
over time as needs change. In addition, older people spend more time at home than any other age group (e.g. Sumner, 2002; Windle et al., 2006; Fox et al., 2017). In many countries, compared with other age groups, older people are more likely to live in older, poorer and less accessible housing stock (e.g. Gaymu, 2003; Walker, 2005).

As a consequence of age-related impairments, older people use local public transport services more than other age groups (e.g. Rosenbloom, \& Winsten-Bartlett, 2002; Rosenbloom, 2004; Tucker, 2005; Shrestha et al., 2017), and need 'walkable' public spaces to perform essential activities such as shopping, or social participation in the neighbourhood (e.g. De Jong Gierveld et al., 2011; Oka, \& Koohsari, 2020). The benefits of walking for physical and mental health are well documented (e.g. Wong et al., 2003; Fisher, \& Li, 2004; Croucher, \& Myers, 2006; WHO, 2019). To make public space "walkable" it should be without architecture barriers, secure, safe in relation to traffic, with high quality and well-maintained pavements to reduce risk of falls or other accidents, clear signage to aid orientation, regular opportunities both to rest and shelter from extremes of weather (heat, cold, rain), and accessible toilets (e.g. Burton, \& Mitchell, 2006; Michael et al., 2006; CLG, 2008a; Babb, 2020). Many urban areas do not meet these requirements, especially low-density developments based on the predominance of the private car over other forms of transport. In these neighbourhoods, the fragmentation of urban functions and their characteristic lack of non-agefriendly 'walkable' public space limit the possibilities of undertaking journeys by foot, or by public transport (e.g. Handy et al. 2002; Saelens et al., 2003; Oka, \& Koohsari, 2020), and, thus, older people, many of whom cannot drive, are isolated and their only mobility options depend on their own economic resources to pay for services such as taxis or on support from families and friends (e.g. Dellinger et al., 2001; Rosenbloom, \& Winsten-Barlett, 2002; Kemperman et al., 2019).

The need for public facilities and services for older people within a walkable distance from home is another requirement for age-friendly urban spaces. Older people make intensive use of the environment immediate to their home (Jones et al., 2007). Consequently, key facilities that are crucial for maintaining independence and autonomy such as retail outlets, leisure facilities and primary health and care services should be located within the immediate environment (e.g. Keating, \& Scharf, 2012; Kemperman et al., 2019). Again, low-density, single-use residential areas with dispersed facilities and services cannot be considered 'age friendly'.

Green areas are another environment issue that must be considered. Numerous studies have highlighted the positive effects of green spaces on health (e.g. Bell et al., 2008, Croucher, \& Myers, 2008; Enssle, \& Kabisch, 2020). Contact with nature reduces stress (Kaplan, 2001; Korpela, \& Ylen, 2007; Van den Berg et al., 2007) leads to increased physical activity and its associated physical and mental health benefits (e.g. Diez, 2003; Evans, 2003; Edwards, \& Tsouros, 2006; Enssle, \& Kabisch, 2020), and encourages participation and social interaction between neighbours (Holland et al., 2007; Sugiyama, \& Thompson, 2007; Sugiyama et al., 2009; Enssle, \& Kabisch, 2020). Parks should be located in the core of urban areas close to where people live. Nonetheless, many cities lack green spaces in proximity to residential areas. In some cases, green areas are concentrated in large parks located in peripheral positions, distant from where people live. Other common problems are the existence of architectural barriers, and absence of age-friendly features, for example, benches or toilet facilities.

Finally it is worth underlining that climate is a cross-sectional variable that influences older people's use of all physical environmental domains (housing, public transport and mobility, public spaces, green areas, and facilities and services). Extremes of heat, cold, inclement weather, ice, snow, and seasonal changes all create additional environmental stresses for older people (e.g. Harvison et al., 2011; Rantanen et al., 2012; Li et al., 2013). 


\section{Developing process of age-friendly urban planning}

\subsection{Theoretical backgrounds}

Before older people's needs were considered in urban planning theory, a wide range of social science disciplines, notably sociology, social policy, gerontology, and geographical gerontology developed several approaches to the relationship between built environment and older people, which make up the theoretical backgrounds of age-friendly urban planning.

In the last third of the 20th Century, older people's needs progressively gained greater recognition in the academic, policy and political fields, particularly in North America, Australia and Europe due to the more intense ageing process of these regions. Initially, this attention focused on sectorial issues such as housing, public transport and social and health care services. Most initiatives were based on the 'ageing in place' principles. The concept of 'ageing in place' refers to the goal of promoting and maximizing opportunities for independent living for older people by providing adequate housing conditions and appropriate social care. Ageing in place is widely considered to be the best approach to implement housing and care policies for older people (e.g. Heywood et al., 2001; Heywood, 2004; Weil, \& Smith 2016). 'Ageing in place' allows: the avoidance of the emotional stress of moving home (Heywood et al., 2001); reduction in costs of providing health and support services (Chappell et al., 2004; Grabowski, 2006); and maintenance of social networks, independence, autonomy, and identity (Scharf, \& Smith, 2004; Smith, 2009; Wiles et al., 2011). 'Ageing in place' also supports older people's commonly expressed preference and aspiration to remain living independently in their own homes for as long as possible (AARP, 2006; Croucher, 2008).

In the 21st century, however, older people's needs have been progressively more broadly understood. Current thinking on 'ageing in place', influenced by socioecological models and environmental gerontology, considers both the personal environment -housing- but also how wider social and physical environments impact on older people's well-being and quality of life (Pynoos, \& Nishita, 2007). For instance, the influential ecological theory of ageing (or competence-press model) originally developed by Lawton and Nahemow (1973) argues that individual behaviour is the result of two driving factors: the competence of the (older) person, determined by his or her physical and mental health, and age-related impairments, and the press of the environment, such as housing conditions (Lawton, 1982). Similarly, environmental gerontology, drawing on the ecological theory of ageing, applies a multidisciplinary framework to analyse and optimise the interaction between older people and their social and physical environments on the basis of preserving "as-independent-aspossible” everyday life (e.g. Kendig, 2003; Wahl, \& Lang, 2003; Phillipson, 2004, 2011; Phillips et al., 2005; Weil, \& Smith, 2016).

Other related disciplines such as geographical gerontology have widened approaches to addressing age related problems and, consequently, have contributed to bringing ageing to the urban planning agenda. In particular, geographical gerontology has focused on the relationship between older people and their environments at different levels that range from home and its meaning (microscale) to the global-regional-local scale continuum (macro-scale) (Andrews et al., 2007).

\subsection{Age-friendly urban planning: theoretical frameworks}

The development of an age-friendly urban planning theory has been rather paradoxical. From the 1980s, essentially three main currents of urban planning thinking can be identified (sustainable urbanism, new urbanism, and smart growth) that, although none of them fully address the challenges of population ageing, incorporate certain guidelines that are in essence age-friendly. 
Sustainable urbanism pursues maximum environmental protection, social equity, and a coherent economic model (e.g. Farr, 2008; Slone et al., 2008; Salat, 2011) using six strategic mechanisms: land-use planning integrated with the ecosystem; land-use mix and coherent urban forms to achieve liveable built environments; social equity supported by an adequate land use regulation; sustainable local economy; regional responsibility to promote collaboration between urban areas; and establishment of fees for polluters. The sustainable city must be compact, with mixed land-use and moderate land consumption. The road network has to give priority to non-motorized and public means of transport, and it has to be structured by nodes which should be integrated within urban growth (e.g. Berke, \& Manta-Conroy, 2000; Berke, 2002; Kenworthy, 2006).

New Urbanism is a movement characterized by urban compactness, relatively high density, walkable streetscapes, and high residential mix in terms of typology, tenure, location and affordability (e.g. Falconer, 2001; Talen, 2005; Grant, 2006; Garde, 2020). The purpose is to promote efficient and varied land-use to avoid urban sprawl. Public space has to be primarily designed for pedestrians, giving priority to non-motorized transportation options, high street connectivity, and a road network hierarchy that distinguishes between predominantly pedestrian spaces and road traffic. As a result, essential shops and services can be located within a ten-minute walking distance from home.

Smart Growth shares numerous premises with New Urbanism (Godshalk, 2004). Both schools propose a compact, dense and mixed-use urban environment designed for pedestrians and for an efficient public transport system (Handy, 2005; Gren et al., 2019). Smart Growth, however, advocates for a more elaborate intervention in the built environment, including interventions to increase density and to restructure deprived urban areas. Mainly in the United States, the smart growth school is increasingly acknowledged as an age-friendly planning approach (e.g. Howe, 2001; Grant, 2006; Salomon, 2006; US EPA, 2009; Chao, 2017). The American Planning Association (APA) uses the term 'multigenerational planning' to describe the application of smart growth principles, as these principles address the needs of both older people and children, promoting security, inclusiveness, and social participation (e.g. APA, 2011; Warner, \& Zhang, 2019). To date, multigenerational planning constitutes the most developed attempt to develop an age-friendly urban planning theory. At technical level, multigenerational planning calls for the implementation of the so-called TrafficOriented Development (TOD) and inclusionary zoning. These techniques are discussed below.

\section{Defining age-friendly urban planning}

\subsection{General urban planning criteria}

The literature on the inadequacy of built environment to meet older people's needs, and associated theoretical frameworks from social policy and environmental gerontology enable the definition of age-friendly urban planning. It should be based on three main principles: compactness, density, and diversity. A more dense and compact urban environment results in more efficient and effective public transport systems, and increases opportunities for 'active' transport (walking, cycling) (e.g. Handy et al., 2002; Saelens et al., 2003; Michael et al., 2006; Harrell et al., 2009; D'Onofrio, \& Trusiani, 2018). This model reduces car use, and associated noise and air pollution, promoting healthier urban environments and improving residents' quality of life (e.g. NSWG, 2001, 2004; Fisher, \& Li, 2004). Diversity must be achieved through mixed use developments in which residential uses are combined with commercial and tertiary activities. When density reaches a certain level, a diversity of uses is feasible as there are a sufficient number of potential users and customers. Likewise, a diverse housing supply has to be promoted by urban planning to meet the housing needs of the 
whole population, including older people. Logically, extensions, blocks and similar typologies of urban growth are the best manner to achieve these objectives.

While these urban planning principles might contribute to enhancing older people's autonomy, independence, well-being and quality of life, by themselves they do not solve all the physical environmental barriers that older people may face. To develop a more comprehensive approach, these general principles need to be supported by specific, evidence-based urban planning tools, notably inclusionary zoning and TOD, but also more specific planning criteria for the design of public spaces, including green spaces, and the provision of health and care services.

\subsection{Housing criteria: the inclusionary zoning technique}

Ensuring access to decent and adequate housing for the entire population is one of the main social objectives of urban planning. Inclusionary zoning is the most suitable urban planning instrument for promoting a range of housing options including options suitable for older people.

Inclusionary zoning, (also known as incentive zoning or mixed-income housing programmes) is an urban planning technique which integrates housing policy within urban planning by establishing a certain percentage of affordable dwellings (for sale or to rent) in new residential development projects at prices below market rates for lower-income households. It can also be adopted to increase the land supply for building supported housing schemes and other alternative residential options for older people with moderate and high levels of dependency. At present, this technique is applied in such diverse countries as United States, Canada, India, Australia, South Africa, New Zealand, Ireland, Spain and United Kingdom (Bosch, 2009; Calavita, \& Mallach, 2009). Research has demonstrated the effectiveness of inclusionary zoning in increasing the supply of affordable housing (e.g. Crook et al., 2006; Been et al., 2007; Whitehead, 2007; Dawkins et al., 2017).

\subsection{Mobility criteria: The Transit-Oriented Development}

Transit-oriented development (TOD) and similar instruments (i.e. accessibility zoning) represent an integrated approach to transportation and land use planning that can increase mobility options for older people. A TOD urban environment is a residential area planned with a relatively high density and mix of uses, which has a centre where a public transport station (metro, train, bus, etc.) is located (Ditmar, \& Ohland, 2004; Knowles et al., 2020). Technically, TOD is based on charting areas of mobility for pedestrians and cyclists (walking and cycling catchments) simultaneously with the definition of urban planning. The potential mobility area of a pedestrian can be delimited by a circle of 400 meters radius, or a distance of 800 meters or 10 minutes walking from a public transport stop, while the cycling catchment area is around a mile, the distance usually covered in five minutes on a bicycle (WA Planning Commission, 2000). Once walking and cycling catchments are defined, the highest residential densities and building intensities are then assigned to areas closer to the poles of mobility, where public space for pedestrians and cyclists is prioritized over the car. It is within these areas where most of the services, shops and facilities should be located. Experience indicates that the most satisfactory and feasible solutions are achieved when older people, transport providers, and other stakeholders are collectively involved in their design and implementation (OECD, 2003; Snell, \& Jones, 2007).

\subsection{Criteria for public space design}

In addition to mobility requirements, the pedestrian road system needs a high degree of interconnection, which can be achieved through a high-density street network crossed by open 
corridors. Many older people have difficulty in walking for more than 15 minutes uninterrupted, thus elements such as benches and public toilets are also needed (Newton et al., 2010). Furthermore, to reduce the high rate of traffic accidents in which older people are involved, a reconsideration of the relationship between pedestrians, cyclists and other road users, that is, the street concept is needed (CLG, \& DFT, 2007). Junctions and pedestrian crossings are usually the most unsafe elements of public space. Appropriate signposting, traffic lights and a suitable time given to cross the road in relation to walking speed are some of the most common requirements of older people in this field (Asher et al., 2012).

\subsection{Criteria for green areas}

Green areas should meet certain requirements of location, accessibility, design, safety and quality to facilitate access to all residents, (CABE, 2006, 2007). A homogeneous distribution of smaller local green areas in all neighbourhoods would be preferable to single large parks distant from residential zones. These local green areas should interconnect with the main network of cycle paths, pedestrian streets, and public transport (NSWG, 2004; Acebillo 2009), and be designed with agefriendly inclusive elements. If people perceive that green areas are unsafe, their use is reduced dramatically, thus proper lighting, police presence, implementation of CCTV, good maintenance, and good design that provides visual control of the environment (Waters et al., 2008) are some measures that can improve both real and perceived fear of crime. It is critical to promote a sense of belonging or attachment to place, Research indicates that the main factors that underpin this sense of belonging are: safety, walkability, and a design that facilitates social relationships (e.g. Peace et al., 2005; Phillipson, 2007; Cattell et al., 2008; Sun et al., 2020).

\subsection{Criteria for health and care services}

Meeting the health and care needs of the growing numbers older people is a major challenge for the public sector. In order to follow the 'ageing in place' principle, decentralisation of primary health and care provision for older people at community level is needed (Littleford, \& Kralik, 2010). With regard to the health and care related public facilities for older people, urban planning can contribute through ensuring an adequate supply of land designated for their use, located close to public transportation stops and in more dense residential areas or at least within a walkable distance from them. This approach requires coordination between health and care providers during all urban planning process.

\section{An evaluation of the role of urban planning in the international initiatives to promote age-friendly cities}

\subsection{Evaluation methodology}

The purpose of this section is to evaluate how far urban planning has been considered in the major international programmes for developing age-friendly cities. Qualitative document analysis (QDA) also referred to as ethnographic content analysis (ECA) was used for identifying, locating, document coding and analysing the programme documents (e.g. Altheide 1996; Altheide et al. 2008). The QDA protocol has been as follows.

The programmes have been identified through an electronic search of papers and grey literature written in English. The evaluation considers only those programmes that met the following two criteria: programmes implemented at a supranational level, notably WHO's Age-Friendly Cities 
programme; and programmes implemented at a national level that are not based on the WHO's Age-Friendly Cities programme. The types of documents reviewed for the QDA include strategic, implementation and guideline of each programme available in the public domain.

On the basis of the age-friendly urban planning guidelines defined in the previous section, the document analysis was conducted in three consecutives hierarchical (general-to-particular) steps. The first step considers the general approach to the role of urban planning in each programme. All programmes have been classified into two groups (Table 1): those that have explicitly highlighted urban planning as a key issue or priority to create age-friendly built environments; and those that do not mention "urban planning" or use any other planning-related terms such as "zoning", "town planning", “city planning", "land-use planning”, or "spatial planning".

The second step looks at the level of recognition of the general age-friendly urban planning criteria (compactness, density, and diversity). According to how these three criteria have been considered in the documents, programmes are sorted into three categories: those that literally or explicitly advocate for these criteria; those that just partly acknowledge them in an indirect way, that is, not as general urban planning criteria but as specific criteria for certain urban aspects such as public transport or services; and those that do not consider them literally, explicitly, or in an indirect way (Table 2).

The third step focusses on the level of development of specific urban planning guidelines related to housing, mobility, public space, green areas, and health and care services (Table 3). When a document recommends or promotes the implementation of urban planning instruments such as TOD and inclusionary housing, or provides concrete urban planning guidelines to tackle certain specific problems in housing, mobility, public spaces, green areas and health care services, it is considered as "high recognition". When these guidelines are ambiguous or vague, or a document only establishes a relationship between urban planning and these areas in terms of cross sectoral involvement, coordination or similar, it is rated as "limited recognition". A document is rated as "no recognition" when it neither considers specific urban planning instruments nor recognises any relationship between planning and these areas. To substantiate the analysis of all steps, detailed quotations are provided (Tables 1, 2 and 3).

\subsection{A general overview of the role of urban planning}

Six programmes were identified: one international project by the World Health Organization (WHO); one programme in Australia, one in the United Kingdom, and three in the United States and (see Table 1).

The Age-Friendly Cities Project promoted by WHO initially formed by a network of 33 cities now currently spans 37 countries with over 400 cities and communities involved (Buckner et al., 2019). According to $\mathrm{WHO}$, an age-friendly city is one with an inclusive and accessible urban environment that promotes active ageing, optimizing opportunities for health, participation and security (WHO, 2007a; Kalache, \& Plouffe, 2010;). Cities participating in the project are committed to develop, implement and evaluate a plan to improve urban conditions of older people under the supervision and guidance of $\mathrm{WHO}$. The protocol for participation was defined in 2006, and a project guide published in 2007 (WHO, 2007a, 2007b). While the project guide provides an extensive list of physical and social elements of the urban environment that define a city as age-friendly, urban planning issues have not been specifically considered by WHO. 
Table 1. Recognition of urban planning as a key issue to promote agefriendly cities in the international programmes

\begin{tabular}{|c|c|}
\hline Programme & Is urban planning considered a key issue/priority to create age-friendly built environments? \\
\hline $\begin{array}{l}\text { WHO } \\
\text { Age-friendly city (1) }\end{array}$ & $\begin{array}{l}\text { NO } \\
\text { "Urban planning" or other similar terms have not been mentioned in the programme. }\end{array}$ \\
\hline $\begin{array}{l}\text { Australia } \\
\text { Age-friendly urban } \\
\text { environments } \\
\text { (2) }\end{array}$ & $\begin{array}{l}\text { YES } \\
\text { "The development of strategic capacity-building initiatives will support local government in } \\
\text { planning for an ageing population. Emphasis will be placed on the importance of conducting } \\
\text { planning at the local level and assessing capacity-building opportunities that assist local } \\
\text { councils to meet the needs of the growing older population." (ALGA, 2004, p. 7) } \\
\text { "Integrate the needs of seniors in urban and community planning, particularly housing, } \\
\text { transport, health and social services." (ALGA, 2006, p. 12) }\end{array}$ \\
\hline $\begin{array}{l}\text { UK } \\
\text { Lifetime } \\
\text { neighbourhood } \\
\text { (3) }\end{array}$ & $\begin{array}{l}\text { YES } \\
\text { "Better representation of the issues of Lifetime Neighbourhoods and an ageing population } \\
\text { must be made in local and regional strategies." (...) "Regional Housing and Planning Boards } \\
\text { must ensure that statutory guidance, for example the Regional Spatial Strategy, makes a } \\
\text { strong priority of the needs of an ageing population." (...) "Planners must be ready to seize } \\
\text { strategic opportunities to plan for an ageing population as and when they occur, whether for } \\
\text { new communities or existing ones." (Harding, 2007, p. 7) } \\
\text { "Regional and local plans are now required to take proper account of ageing and the needs } \\
\text { of older people" (CLG, 2008b, p. 15) } \\
\text { "A commitment in national planning policy statements that the needs of an ageing } \\
\text { population must be provided for." (CLG, 2008b, p. 23) }\end{array}$ \\
\hline $\begin{array}{l}\text { United States } \\
\text { Livable community } \\
\text { (AARP) } \\
\text { (4) }\end{array}$ & $\begin{array}{l}\text { YES } \\
\text { "Proper land-use planning and design are critical to developing livable communities." (AARP, } \\
2011 \text {, p. 1) } \\
\text { "... many of the solutions for successful aging will arise through multi-faceted local planning } \\
\text { and decision-making-be it land development planning, zoning, transportation planning, road } \\
\text { design or housing policy." (Oberlink, 2008, Foreword) } \\
\text { "...a community's capacity to provide affordable and accessible housing, transportation, and } \\
\text { other services to specifically meet older people's needs depend to a large degree on its land } \\
\text { use and zoning policies..." (Oberlink, 2008, Executive Summary) }\end{array}$ \\
\hline $\begin{array}{l}\text { United States } \\
\text { Livable community } \\
\text { (NAAA, PFLC) } \\
\text { (5) }\end{array}$ & $\begin{array}{l}\text { YES } \\
\text { "Making a community more livable for people of all ages often requires significant changes } \\
\text { in land use patterns." (NAAA, \& PFLC, 2007, p. 16) } \\
\text { "Some of the issues underlying residents" ability to age in place successfully may be } \\
\text { controversial. In many communities, for example, land use and zoning are key factors and } \\
\text { may cause friction between competing value systems." (NAAA, \& PFLC, 2007, p. 49) } \\
\text { There is a checklist of key planning and zoning features that an aging-friendly community } \\
\text { should meet (NAAA, \& PFLC, 2007, p. 69) } \\
\text { "Land use and other planning processes can significantly impact the ability of an older adult } \\
\text { to age successfully in their home and community." (NAAA, 2011, p. } 4 \text { ) } \\
\text { "Communities need to broadly re-examine existing planning policies to reflect the needs of } \\
\text { an aging population (...)" (NAAA, 2011, p. 4) }\end{array}$ \\
\hline $\begin{array}{l}\text { United States } \\
\text { Elder Friendly } \\
\text { community (6) }\end{array}$ & $\begin{array}{l}\text { NO } \\
\text { "Urban planning" or other similar terms have not been mentioned in the programme. }\end{array}$ \\
\hline
\end{tabular}

Notes: (1) (WHO, 2007a, 2007b; Kalache, \& Plouffe, 2010); (2) (ALGA, 2004, 2006; ALGA et al., 2009); (3) (Harding, 2007; CLG, 2008b); (4) (Baron, 2000; AARP, 2005, 2006, 2010, 2011a, 2011b; Guterbock et al., 2005; Oberlink, 2008; Harrell et al., 2009); (5) (Dalrymple, 2005; NAAA, \& PFLC, 2007; NAAA, 2011); (6) (Feldman et al., 2003; AdvantAge Initiative, 2004a, 2004b;). Source: Own elaboration based on qualitative document analysis of selected programmes

The National Strategy for an Ageing Australia defined six broad areas for intervention to ensure adequate living conditions for older people: education, training, housing, transport, cultural and recreational opportunities, and care services (CA, 2001; PAFA, 2002). This initiative was further developed in 2004 through the Australian Local Population Ageing Action Plan 2004-2008 (ALGA, 2004) and a comprehensive guide to assist local authorities was published in 2006 (ALGA, 2006). This guidance highlighted six major objectives: encourage collaboration among stakeholders to promote awareness of the ageing society, improve information and support age-friendly urban programmes; create safer and securer pedestrian environments; encourage careful planning and design with the older people; improve mobility options for older people; improve leisure services, public spaces and pedestrian routes; and promote adequate housing supply, in terms of diversity, quantity, accessibility, location and integration with planning. Crucially the guide argues that older people's needs for housing, transport, health and social services should be integrated into urban 
planning, and calls for: mixed-use developments, the execution of age-friendly community renewal programmes; and improving walkability, mixed use and street connectivity. The guide also proposes a social impact assessment framework for addressing ageing-related issues within the planning process.

In the United Kingdom (UK), urban policy to adapt urban environments to older people has been influenced by the concepts of 'lifetime neighbourhood', and 'lifetime home' (Harding, 2007). 'Lifetime homes' are those houses adaptable enough to match a lifetime's changing needs (CLG, 2008b). The 'lifetime neighbourhood' concept is less well defined, recognising a role for urban planning, but not offering any specific guidance or techniques. Nevertheless, the 'lifetime neighbourhood' concept has been embedded in strategic plans for several major UK cities, including Manchester (Manchester City Council, 2004, 2009), Edinburgh, Southampton, Newcastle (NCC, \& NU, 2009) and London (GLA, 2006). In the United States, four organizations: the American Association of Retired Persons (AARP), The AdvantAge Initiative, the National Association of Area Agencies on Aging (NAAA), and Partners for Liveable Communities (PFLC) have promoted nationwide initiatives to promote age-friendly urban models.

Based on a series of studies (Baron, 2000; AARP, 2005; Guterbock et al., 2005) the AARP developed the "Livable Community" model. A livable community is defined as an environment "that has affordable and appropriate housing, supportive community features and services, and adequate mobility options, which together facilitate personal independence and the engagement of residents in civic and social life." (Guterbock et al., 2005, p. 4). The AARP programme highlights the importance of urban planning in developing livable communities.

The AdvantAge Initiative has also devised its own age-friendly city model. However, the AdvantAge Initiative does not consider urban planning, focussing on four areas: housing and safety, physical and mental health, independence of frail and disabled people, and social and civic participation (Feldman et al., 2003; AdvantAge Initiative, 2004a, 2004b).

In 2007 NAAA and PFLC jointly published guidance for developing 'Livable Communities' (NAAA, \& PFLC, 2007) emphasizing areas for intervention, including: housing, transport, health services and welfare, culture and education, public safety, volunteering and civic participation, and planning. In fact, urban planning is considered by NAAA and PFLC a key issue to create age-friendly environments and, for instance, there is a section on it in the guidance (NAAA, \& PFLC, 2007, pp. 1519) and a detailed development of age-friendly urban planning guidelines.

In summary, while there are various terminologies used to define an age-friendly urban environment, there is a shared recognition that initiatives must be comprehensive, and promote the construction and maintenance of physical and social environments that facilitate an independent and active life (Hanson, 2006; Bernard, \& Scharf, 2007; Lui et al., 2009). However, recognition of the role of urban planning in promoting age-friendly urban environments varies substantially across programmes. While urban planning is not considered by WHO nor the AdvantAge Initiative, it is acknowledged as an important component in the Australian and British models and in the programmes developed by the AARP, the NAAA and PFLC because of its relation with public transport, mobility, housing, services and public space (Table 1).

\subsection{The recognition of the general age-friendly urban planning criteria}

Examining to what extent the general age-friendly urban planning features has been recognized in the international initiatives (Table 2), a significant gap between the academic world and the models reviewed is found. Despite the wide academic consensus on the need for a compact, dense and diverse built environment, only three programmes openly advocate for them: the Australian 
programme, and the two 'livable community' models developed by the AARP and by the NAAA and PFLC in the United States. The WHO project suggests the importance of these principles in an indirect way, and they are not considered by the UK 'lifetime neighbourhood' initiative, nor by the 'elder friendly community' model. In terms of its influence on public policies globally, the absence of a clear recognition of these characteristics in WHO's project is particularly problematic.

Table 2. Recognition of general age-friendly urban planning criteria in international programmes to promote age-friendly cities

\begin{tabular}{|c|c|c|c|}
\hline Programme & Compactness & Density & Diversity \\
\hline \multirow{2}{*}{$\begin{array}{l}\text { WHO } \\
\text { Age-friendly city } \\
\text { (1) }\end{array}$} & YES (indirect way) & YES (indirect way) & YES (indirect way) \\
\hline & \multicolumn{3}{|c|}{$\begin{array}{l}\text { "Services (should be) are clustered, located in close proximity to where older people live and can } \\
\text { be easily accessed" (WHO, 2007a, p. 19); "Designated transport stops (should be) are located in } \\
\text { close proximity to where older people live..." (WHO, 2007a, p. 28); "Housing (should be) is located } \\
\text { close to services and facilities. (WHO, 2007a, p. 37) }\end{array}$} \\
\hline \multirow[t]{2}{*}{$\begin{array}{l}\text { Australia } \\
\text { Age-friendly } \\
\text { urban } \\
\text { environments } \\
\text { (2) }\end{array}$} & YES (indirect way) & $\begin{array}{l}\text { YES (literally or explicitly) } \\
\text { "...low density urban } \\
\text { development, a characteristic } \\
\text { of many communities, is not } \\
\text { particularly age-friendly." } \\
\text { (ALGA, 2006, p. 3) }\end{array}$ & $\begin{array}{l}\text { YES (literally or explicitly) } \\
\text { "Stimulate development of } \\
\text { mixed-use projects that } \\
\text { encourages an environment } \\
\text { built to the human scale...." } \\
\text { (ALGA, 2006, p. 12) }\end{array}$ \\
\hline & \multicolumn{3}{|c|}{$\begin{array}{l}\text { "Neighbourhoods that have good access to destinations including shops, schools, public } \\
\text { transport and other facilities and have connected street networks, mixed land use and higher } \\
\text { densities are associated with increased walking and cycling for transport." (ALGA et al., 2009, p. } \\
\text { 6) }\end{array}$} \\
\hline $\begin{array}{l}\text { UK (3) Lifetime } \\
\text { neighbourhood }\end{array}$ & NO & NO & NO \\
\hline $\begin{array}{l}\text { United States } \\
\text { Livable } \\
\text { community } \\
\text { (AARP) } \\
(4)\end{array}$ & $\begin{array}{l}\text { YES (literally or explicitly) } \\
\text { "...a livable community } \\
\text { incorporates mixed-use } \\
\text { development, exhibits a } \\
\text { compact development } \\
\text { pattern, minimizes highly } \\
\text { dispersed development } \\
\text { patterns ("sprawl")..." } \\
\text { (Guterbock et al., 2005, p. 15) } \\
\text { "These policies should } \\
\text { encourage: mixed-use } \\
\text { development and location of } \\
\text { housing within easy walking } \\
\text { distance of shopping, } \\
\text { recreation, public } \\
\text { transportation, and services;" } \\
\text { (AARP, 2011a, p. 5) }\end{array}$ & $\begin{array}{l}\text { YES (literally or explicitly) } \\
\text { "High density and mixed use } \\
\text { support walkability..." } \\
\text { (Guterbock et al., 2005, p. 88). } \\
\text { “...such areas are frequently } \\
\text { the most cost-effective for } \\
\text { transit service because of } \\
\text { population density..." (AARP, } \\
\text { 2005, p. 22) } \\
\text { "In larger, dense urban and } \\
\text { suburban settings, transit can } \\
\text { provide a hub that greatly } \\
\text { improves transportation } \\
\text { options." (AARP, 2011a, p. 4) }\end{array}$ & $\begin{array}{l}\text { YES (literally or explicitly) } \\
\text { "Pressing for mixed-use } \\
\text { development" (AARP 2005: 82); } \\
\text { "... to encourage more diverse } \\
\text { neighborhoods" "Zoning and } \\
\text { building codes may be revised } \\
\text { to promote mixed-use } \\
\text { development..." (AARP, 2011a, } \\
\text { p. 6); } \\
\text { "Land-use planning that } \\
\text { connects residents to jobs, } \\
\text { services, retail, recreation, and } \\
\text { entertainment through an } \\
\text { interconnected network of } \\
\text { Complete Streets sustainably } \\
\text { increases transportation } \\
\text { options and social } \\
\text { interactions." } \\
\text { (AARP, 2011a, p. 2) }\end{array}$ \\
\hline $\begin{array}{l}\text { United States } \\
\text { Livable } \\
\text { community } \\
\text { (NAAA, PFLC) } \\
\text { (5) }\end{array}$ & $\begin{array}{l}\text { YES (indirect way) } \\
\text { "These (housing options for } \\
\text { older people) should be as } \\
\text { close as possible to } \\
\text { transportation links and/or } \\
\text { walkable distance from daily } \\
\text { needs like medical services } \\
\text { or shopping." } \\
\text { (NAAA, 2011, p. 3) }\end{array}$ & $\begin{array}{l}\text { YES (literally or explicitly) } \\
\text { "Zoning and development } \\
\text { standards were amended to } \\
\text { allow higher densities and } \\
\text { mixed uses." (NAAA, \& PFLC } \\
2007, \text { p. 17) } \\
\text { "The number of lots permitted } \\
\text { per acre and other density } \\
\text { restrictions can be lifted to } \\
\text { accommodate the needs of } \\
\text { older adults" (NAAA, 2011, p. 15) }\end{array}$ & $\begin{array}{l}\text { YES (literally or explicitly) } \\
\text { "One of the most effective } \\
\text { policy ... for affordable and } \\
\text { convenient transportation is } \\
\text { the concentration of mixed- } \\
\text { use development..." } \\
\text { (Dalrymple, 2005, p. 7); "Does } \\
\text { the zoning code allow mixed- } \\
\text { use and pedestrian-friendly } \\
\text { development in appropriate } \\
\text { areas (such as town centers)? } \\
\text { (NAAA, \& PFLC, 2007, p. 69) }\end{array}$ \\
\hline $\begin{array}{l}\text { United States } \\
\text { Elder Friendly } \\
\text { community (6) }\end{array}$ & NO & $\begin{array}{l}\text { YES (indirect way) } \\
\text { "Seventy-five percent of older } \\
\text { people live in rural or } \\
\text { suburban areas where there is } \\
\text { insufficient population density } \\
\text { to support traditional public } \\
\text { transit." (Feldman et al., 2003, } \\
\text { p. 35) }\end{array}$ & NO \\
\hline
\end{tabular}

Source: Own elaboration based on qualitative document analysis of selected programmes 


\subsection{The development of specific urban planning guidelines}

Similarly, no specific urban planning guidelines have been proposed in the "elder friendly community' model or WHO's project except in relation to the health and care services. On the other hand, the level of recognition of specific urban planning guidelines is limited in the British programme given that it just points out that cross sectoral involvement in the planning process is needed.

However, the Australian programme and the two American 'livable community' models establish several urban planning guidelines in respect of housing, mobility and transport, public space, green areas, and health and care services (Table 3). There is a relative consensus in these three models on the following: housing and transportation policies should be integrated into urban planning to offer a wider range of residential and mobility options for older people; street connectivity must be promoted by planning; and urban planning can contribute to meet the growing needs of health and care services by adequate zoning requirements based on proximity to residential areas. Although four programmes suggest that green spaces and neighbourhood parks might be promoted through urban planning, the Australian programme is the only one that provides clear guidelines in this field. Regarding the implementation of specific urban planning instruments, only the AARP's model advocates explicitly for the Transit-Oriented Development and, as the Australian model, for the inclusionary zoning.

\section{Conclusions and discussion}

This paper demonstrates that urban planning has the tools and the potential to assist with development of urban environments that meet the needs of an ageing population. Nevertheless, urban planning still appears to sit on the margins of the wider debate and movement to create agefriendly cities.

There is, however, a broad theoretical consensus on certain general criteria that urban environments should meet for being considered age-friendly: compactness, density, and diversity. The origins of these general criteria are multiple. On one hand, they are the result of the on-going development of the 'ageing in place' concept. On the other hand, they also come from urban planning theory itself, in particular, from multigenerational planning, which is based on smart growth premises.

Beyond these general urban planning criteria, some specific planning instruments can decisively contribute to develop a more comprehensive age-friendly urban planning approach. Inclusionary zoning techniques can address the housing needs of older people and increase the supply of land to promote residential options for older people with care needs; older people's mobility can be enhanced through the Transit-Oriented Development planning method; the inclusion of certain planning criteria such as connectivity and proximity to residential areas can result in more agefriendly open spaces and green areas; and the consideration of the primary health and care needs of older people in the planning process can facilitate the provision of such services.

Nonetheless, there is a notable gap between theoretical framework and its practical implementation. Urban planning plays a minor role in the most influential international initiative to promote age-friendly environments conducted by WHO. Only three out the six models analysed (the Australian programme and the two 'livable community' models developed by the AARP and by the NAAA and PFLC in the United States) incorporate specific age-friendly urban planning guidelines. Their technical development is, however, rather disparate. 
Table 3. Level of recognition of specific age-friendly urban planning criteria and instruments in international programmes to promote age-friendly cities

\begin{tabular}{|c|c|c|c|c|c|}
\hline Programme & Housing & $\begin{array}{l}\text { Mobility and } \\
\text { transport }\end{array}$ & $\begin{array}{ll}\text { Public } & \text { space } \\
\text { and } & \text { street } \\
\text { system } & \end{array}$ & $\begin{array}{l}\text { Health and care } \\
\text { services }\end{array}$ & Green areas \\
\hline $\begin{array}{l}\text { WHO } \\
\text { Age-friendly } \\
\text { city (1) }\end{array}$ & NO & NO & NO & $\begin{array}{l}\text { HIGH } \\
\text { "Having well- } \\
\text { located, easily } \\
\text { accessible } \\
\text { health services } \\
\text { is } \\
\text { fundamentally } \\
\text { important for } \\
\text { older people..." } \\
\text { (WHO, 2007a, p. } \\
67) \text { "Health and } \\
\text { social services } \\
\text { are } \\
\text { conveniently } \\
\text { located" (WHO, } \\
\text { 2007b, p. 4) }\end{array}$ & NO \\
\hline $\begin{array}{l}\text { Australia } \\
\text { Age-friendly } \\
\text { urban } \\
\text { environments } \\
\text { (2) }\end{array}$ & $\begin{array}{l}\text { HIGH } \\
\text { "Develop an } \\
\text { age friendly } \\
\text { assessment } \\
\text { procedure for } \\
\text { housing } \\
\text { development } \\
\text { applications." } \\
\text { (ALGA, 2006, p. } \\
\text { 18) "Establish } \\
\text { mechanisms to } \\
\text { encourage } \\
\text { suitable } \\
\text { housing } \\
\text { outcomes for } \\
\text { seniors such as } \\
\text { developer } \\
\text { contributions, } \\
\text { inclusionary } \\
\text { zoning and } \\
\text { betterment } \\
\text { levies." } \\
\text { (ALGA, 2006, p. } \\
\text { 19) }\end{array}$ & $\begin{array}{l}\text { LIMITED } \\
\text { "Integrate the } \\
\text { needs of } \\
\text { seniors in } \\
\text { urban and } \\
\text { community } \\
\text { planning, } \\
\text { particularly } \\
\text { housing, } \\
\text { transport, } \\
\text { health and } \\
\text { social } \\
\text { services." } \\
\text { (ALGA, 2006, p. } \\
\text { 12) }\end{array}$ & $\begin{array}{l}\text { HIGH } \\
\text { "Create } \\
\text { corridors of } \\
\text { open space that } \\
\text { can be used as } \\
\text { recreational } \\
\text { parkland and } \\
\text { movement } \\
\text { systems." "Build } \\
\text { pathways } \\
\text { through } \\
\text { neighbourhoods } \\
\text { to connect } \\
\text { homes with } \\
\text { destinations." } \\
\text { "Review the } \\
\text { existing system } \\
\text { of parks and } \\
\text { tracks and } \\
\text { identify ways to } \\
\text { expand and } \\
\text { improve } \\
\text { connections." } \\
\text { (ALGA, 2006, p. } \\
\text { 16) }\end{array}$ & $\begin{array}{l}\text { HIGH } \\
\text { "...planning and } \\
\text { provision of } \\
\text { services and } \\
\text { programs that } \\
\text { are flexible and } \\
\text { locally } \\
\text { appropriate to } \\
\text { the needs of } \\
\text { older people;" } \\
\text { (ALGA, 2004, p. } \\
\text { 6) } \\
\text { "... nearby } \\
\text { health centres } \\
\text { and } \\
\text { recreational } \\
\text { facilities are all } \\
\text { important } \\
\text { elements that } \\
\text { can positively } \\
\text { affect the } \\
\text { ageing } \\
\text { experience" } \\
\text { (ALGA, 2006, p. } \\
\text { 3) }\end{array}$ & $\begin{array}{l}\text { HIGH } \\
\text { "Neighbourhoo } \\
\text { d parks that are } \\
\text { within walking } \\
\text { and biking } \\
\text { distance of a } \\
\text { person's home } \\
\text { or work can } \\
\text { encourage } \\
\text { greater physical } \\
\text { activity." (ALGA, } \\
\text { 2006, p. 16) } \\
\text { (Initiatives) } \\
\text { "Maintain and } \\
\text { create } \\
\text { neighbourhood } \\
\text { parks." (ALGA, } \\
\text { 2006, p. 16) }\end{array}$ \\
\hline $\begin{array}{l}\text { UK } \\
\text { Lifetime } \\
\text { neighbourhood } \\
\text { (3) }\end{array}$ & $\begin{array}{l}\text { LIMITED } \\
\text { “...a fair and } \\
\text { effective } \\
\text { housing } \\
\text { strategy for an } \\
\text { ageing society } \\
\text { must (...) be } \\
\text { fully } \\
\text { mainstreamed } \\
\text { into all policies } \\
\text { for housing and } \\
\text { planning." (CLG, } \\
\text { 2008b, p. 38) }\end{array}$ & \multicolumn{4}{|c|}{$\begin{array}{l}\text { LIMITED } \\
\text { "Cross-sectoral engagement in planning is essential for lifetime } \\
\text { neighbourhoods. Planners must engage with service providers to ensure } \\
\text { the built environment offers 'age-proofed' communities. For example, } \\
\text { by including provision for accessible local amenities such as civic and } \\
\text { community centres, shops, and the transport, street environment and } \\
\text { aesthetic environment that will encourage older people to participate." } \\
\text { (Harding, 2007, p. 7) }\end{array}$} \\
\hline
\end{tabular}


Table 3 (Continue). Level of recognition of specific age-friendly urban planning criteria and instruments in international programmes to promote age-friendly cities

\begin{tabular}{|c|c|c|c|c|c|}
\hline Programme & Housing & $\begin{array}{l}\text { Mobility and } \\
\text { transport }\end{array}$ & $\begin{array}{ll}\text { Public } & \text { space } \\
\text { and } & \text { street } \\
\text { system } & \\
\end{array}$ & $\begin{array}{l}\text { Health and care } \\
\text { services }\end{array}$ & Green areas \\
\hline $\begin{array}{l}\text { United States } \\
\text { Livable } \\
\text { community } \\
\text { (AARP) } \\
\text { (4) }\end{array}$ & $\begin{array}{l}\text { HIGH } \\
\text { "Inclusionary } \\
\text { zoning and } \\
\text { density } \\
\text { bonuses are } \\
\text { two other local } \\
\text { government } \\
\text { mechanisms to } \\
\text { increase the } \\
\text { availability of } \\
\text { affordable } \\
\text { housing" } \\
\text { (Oberlink, 2008, } \\
\text { p. 5) }\end{array}$ & $\begin{array}{l}\text { HIGH } \\
\text { "TOD can } \\
\text { create compact } \\
\text { livable } \\
\text { communities } \\
\text { that serve the } \\
\text { needs of } \\
\text { people age } 50 \\
\text { and older" } \\
\text { (Harrell et al., } \\
\text { 2009, p. 10) } \\
\text { "The TOD } \\
\text { model, which } \\
\text { integrates a mix } \\
\text { of uses around } \\
\text { a transit hub ... } \\
\text { is one solution } \\
\text { to many of } \\
\text { these } \\
\text { transportation } \\
\text { challenges." } \\
\text { (AARP, 2010, p. } \\
5 \text { ) }\end{array}$ & $\begin{array}{l}\text { HIGH } \\
\text { "Land-use } \\
\text { planning that } \\
\text { connects } \\
\text { residents to } \\
\text { jobs, services, } \\
\text { retail, } \\
\text { recreation, and } \\
\text { entertainment } \\
\text { through an } \\
\text { interconnected } \\
\text { network of } \\
\text { Complete } \\
\text { Streets } \\
\text { sustainably } \\
\text { increases } \\
\text { transportation } \\
\text { options and } \\
\text { social } \\
\text { interactions." } \\
\text { (AARP, 2011a, p. } \\
\text { 2) }\end{array}$ & $\begin{array}{l}\text { HIGH } \\
\text { "To many older } \\
\text { people, access } \\
\text { to health } \\
\text { services means } \\
\text { not only } \\
\text { physical } \\
\text { proximity but } \\
\text { availability of } \\
\text { services as } \\
\text { well." (AARP, } \\
\text { 2005, p. 106) } \\
\text { "These policies } \\
\text { (land use) } \\
\text { determine how } \\
\text { a community } \\
\text { grows; where ... } \\
\text { health } \\
\text { institutions } \\
\text { were be built..." } \\
\text { (Oberlink, 2008, } \\
\text { p. 17) }\end{array}$ & $\begin{array}{l}\text { LIMITED } \\
\text { "A livable } \\
\text { community } \\
\text { offers parks for } \\
\text { walking, } \\
\text { jogging, and } \\
\text { cycling" (AARP, } \\
\text { 2005, p. 118) } \\
\text { ".. they (older } \\
\text { people) should } \\
\text { have the } \\
\text { opportunity } \\
\text { to remain in } \\
\text { the same } \\
\text { community } \\
\text { with the ... } \\
\text { parks, and } \\
\text { services with } \\
\text { which they are } \\
\text { familiar." (AARP, } \\
2010, \text { p. 5) }\end{array}$ \\
\hline \multirow{3}{*}{$\begin{array}{l}\text { United States } \\
\text { Livable } \\
\text { community } \\
\text { (NAAA, PFLC) } \\
\text { (5) }\end{array}$} & \multirow{3}{*}{$\begin{array}{l}\text { HIGH } \\
\text { "...communities } \\
\text { should assess } \\
\text { their land use } \\
\text { plans, zoning } \\
\text { ordinances and } \\
\text { building codes } \\
\text { to promote the } \\
\text { development of } \\
\text { a range of } \\
\text { housing options } \\
\text { that meet the } \\
\text { needs of an } \\
\text { aging } \\
\text { population" } \\
\text { (NAAA, 2011, p. } \\
\text { 3) } \\
\text { "Incorporate } \\
\text { accessory } \\
\text { dwelling units } \\
\text { and senior- } \\
\text { friendly housing } \\
\text { in the zoning } \\
\text { code" (NAAA, \& } \\
\text { PFLC, 2007, p. } \\
\text { 8) }\end{array}$} & $\mathrm{HIGH}$ & $\mathrm{HIGH}$ & $\mathrm{HIGH}$ & \multirow{3}{*}{$\begin{array}{l}\text { LIMITED } \\
\text { "Developing } \\
\text { and promoting } \\
\text { parks and } \\
\text { trails" (NAAA, \& } \\
\text { PFLC, 2007, p. } \\
\text { 31) }\end{array}$} \\
\hline & & \multicolumn{3}{|c|}{$\begin{array}{l}\text { One of the most effective policy that can be } \\
\text { implemented for affordable and convenient } \\
\text { transportation is the concentration of mixed-use } \\
\text { development, where public agencies, health care and } \\
\text { social service providers, commercial establishments, } \\
\text { churches and residential areas are clustered on } \\
\text { interconnected and well-designed streets." } \\
\text { (Dalrymple, 2005, p. 7) } \\
\text { "These (housing options for older people) should be } \\
\text { as close as possible to transportation links and/or } \\
\text { walkable distance from daily needs like medical } \\
\text { services or shopping." (NAAA, 2011, p. 3) }\end{array}$} & \\
\hline & & & & $\begin{array}{l}\text { "...zoning } \\
\text { regulations and } \\
\text { the land use } \\
\text { planning } \\
\text { process may be } \\
\text { invaluable to } \\
\text { advancing } \\
\text { efforts on a } \\
\text { range of fronts, } \\
\text { such as making } \\
\text { health care } \\
\text { facilities more } \\
\text { accessible." } \\
\text { (NAAA, \& PFLC, } \\
2007, \text { p. 49) }\end{array}$ & \\
\hline $\begin{array}{l}\text { United States } \\
\text { Elder Friendly } \\
\text { community (6) }\end{array}$ & NO & NO & NO & NO & NO \\
\hline
\end{tabular}

Notes: See Table 1

Source: Own elaboration based on qualitative document analysis of selected programmes 
The Transit-Oriented Development has only been considered by the AARP, and the inclusionary zoning technique by the AARP and the Australian programme. Hence, from a practical perspective, even though some models advocate planning guidelines, it could be concluded that there is neither a full recognition of the potential of urban planning nor any development or in-depth analysis of an age-friendly urban planning model in the most relevant international programmes to promote agefriendly urban environments. But, despite the absence or partial recognition of urban planning as a key instrument in most of the international initiatives to promote age-friendly environments, these initiatives have decisively contributed to increase the awareness of the inadequacy of built environment for the changing needs of older people and, therefore of the imperative to develop age-friendly urban planning principles.

A key question is therefore, why has urban planning not taken a greater role in creating age-friendly cities? There are a number of possible explanations. At the technical level, urban planning as a discipline may be failing to fully understand the complex and diverse needs of older people, and consequently failing to recognise the discipline's role in shaping environments to promote older people's health, well-being and quality of life (Hockey et al., 2013). At the economic level, broad principles of density, compactness and diversity in urban growth, and techniques such as inclusionary zoning may reduce the developer's profit margins (e.g. Been et al., 2007, p. 8; Bosch, 2009, p. 169; Calavita, \& Mallach, 2009, p. 17). At the political level, planning for longer term societal benefits might (and probably does) come second to planning for short-term gains driven by political and financial concerns.

If these assumptions are correct, it is for urban planning as a discipline to engage more fully with the multi-disciplinary endeavour of creating age-friendly cities through: training and education of its practitioners notably about demographic changes and diverse needs of older people; through promotion and awareness raising of the potential of recognised planning techniques; by challenging notions of short term profit over long term societal gain; and by synthesising and developing a more coherent age-friendly urban planning theory that can be located in urban planning frameworks and crucially planning legislation.

Finally, further research is needed to improve the efficiency and efficacy of urban planning in meeting 'active ageing' goals. For example, little is known about age-friendly urban renewal interventions in low-density developments; how urban planning can address the needs of those with multiple disabilities and impairments, including the increasing numbers of older people living with dementia; or how city planning impacts on the social dimensions of active ageing.

Conflict of interest: Author declares no conflict of interests.

\section{Bibliography}

AARP (2005). Livable Communities: An Evaluation Guide. Washington DC., USA: AARP Public Policy Institute. Retrieved from https://assets.aarp.org/rgcenter/il/d18311 communities.pdf

AARP (2006). The State of America 50+. Washington DC., USA: AARP Public Policy Institute.

AARP (2010). Strategies to Meet the Housing Needs of Older Adults. Washington DC., USA: AARP Public Policy Institute. Retrieved from https://assets.aarp.org/rgcenter/ppi/liv-com/i38-strategies.pdf

AARP (2011a). Policy Book 2011-2012. Washington DC., USA: AARP Public Policy Institute. 
AARP (2011b). Housing for Older Adults: The Impacts of the Recession. Washington DC., USA: AARP Public Policy Institute.

Abbott, P., \& Sapsford, R. (2005). Living on the margins: older people, place and social exclusion. Policy Studies, 26(1), 29-46. DOI: https://doi.org/10.1080/01442870500041660

Acebillo, J. (2009). Urbaging: Designing Urban Space for an Ageing Society, Final Scientific Report. Medrisio, Switzerland: Swiss National Science Foundation. Retrieved from https://trimis.ec.europa.eu/sites/default/files/project/documents/2015051723504377561 NRP54 F SReport 1602 DEF.pdf

AdvantAge Initiative (2004a). Indicator Chartbook National Survey of Adults Aged 65 and Older. New York, USA: Visiting Nurse Service of New York, Center for Home Care Policy and Research.

AdvantAge Initiative (2004b). Housing Cost Burden Casts a Shadow Over Older People's Future. New York, USA: Visiting Nurse Service of New York, Center for Home Care Policy and Research.

ALGA (2004). Australian Local Government Population Ageing Action Plan 2004-2008. Canberra, Australia: Australian Local Government Association.

ALGA (2006). Age-Friendly Built Environment: Opportunities for Local Government. Canberra, Australia: Australian Local Government Association.

ALGA, NHFA, \& PIA (2009). Healthy Spaces and Places: A National Guide to Designing Places for Healthy Living. Canberra, Australia: Australian Local Government Association, National Heart Foundation of Australia and Planning Institute of Australia. Retrieved from http://www.healthyplaces.org.au/userfiles/file/HS\&P\%20An\%20overview.pdf

Alley, D.; Liebig, P., \& Pynoos, J. (2007). Creating elder-friendly communities: Preparations for an aging society. Journal of Gerontological Social Work, 49(1), 1-18. DOI: https://doi.org/10.1300/j083v49n01 01

Altheide, D. (1996). Qualitative Media Analysis. Newbury Park CA, USA: Sage.

Altheide, D.; Coyle, M.; Devriese, K., \& Schneider, C. (2008). Emergent qualitative document analysis. In S. Hesse-Biber, \& P. Leavy. (Eds), Handbook of Emergent Methods (pp. 127-155). New York, USA: Guilford Press.

Andrews, G. J.; Cutchin, M.; McCracken, K.; Phillips, D. R., \& Wiles, J. (2007). Geographical gerontology: The constitution of a discipline. Social Science \& Medicine, 65(1), 151-168. https://doi.org/10.1016/j.socscimed.2007.02.047

APA (2011). Multigenerational Planning. Using Smart Growth and Universal Design to Link the Needs of Children and the Aging Population. Family-friendly Communities. Chicago, USA: American Planning Association, Briefing Papers 02.

Asher, L.; Aresu, M.; Falaschetti, E., \& Mindell, J. (2012). Most older pedestrians are unable to cross the road in time: a cross-sectional study. Age and Ageing, 41(5), 690-694. DOI: https://doi.org/10.1093/ageing/afs076

Babb, c. (2020). What of a walkable urban future? Towards sustainable institutional design for walking. In C. Curtis. (Ed.), Handbook of Sustainable Transport (pp. 100-108). Northampton, USA: Edward Elgar Publishing. DOl: https://doi.org/10.4337/9781789900477.00022 
Baron, P. (2000). Livable Communities: An Evaluation Guide. Washington DC., USA: AARP Public Policy Institute.

Batty, M. (2008). The size, scale, and shape of cities. Science, 319, 769-771. DOI: https://www.science.org/doi/10.1126/science.1151419

Been, V.; Meltzer, R., \& Schuetz, J. (2007). The Effects of Inclusionary Zoning on Local Housing Markets: Lessons from the San Francisco, Washington DC and Suburban Boston Areas. New York, USA: Furman Center for Real State and Urban Policy, New York University. Retrieved from https://furmancenter.org/files/publications/IZPolicyBrief LowRes.pdf

Bell, S.; Hamilton, V.; Montarzino, A.; Rothnie, H.; Travlou, P., \& Alves, S. (2008). Greenspace and Quality of Life: A Critical Review. Stirling, UK: Greenspace Scotland.

Berke, P. (2002). Does sustainable development offer a new direction for planning? Challenges for the Twenty-First Century. Journal of Planning Literature, 17(1), 22-36. DOI: https://doi.org/10.1177/088122017001002

Berke, P., \& Manta-Conroy, M. (2000). Are we planning for sustainable development? Journal of the American Planning Association, 66(1), 21-35. DOI: https://doi.org/10.1080/01944360008976081

Bernard, M., \& Scharf, T. (2007). Critical Perspectives on Ageing Societies. Bristol, UK: Policy Press. DOI: https://doi.org/10.1332/policypress/9781861348906.001.0001

Bosch, J. (2009). How urban planning instruments can contribute in the fight against homelessness. An international overview of inclusionary housing. European Journal of Homelessness, 3, 155-77.

Buckner, S.; Pope, D.; Mattocks, C.; Lafortune, L.; Mukesh Dherani, L., \& Bruce, N. (2019). Developing Age-Friendly Cities: an Evidence-Based Evaluation Tool. Population Ageing 12, 203-223. DOI: https://doi.org/10.1007/s12062-017-9206-2

Burton, E., \& Mitchell, L. (2006). Inclusive Urban Design: Streets for Life. London, UK: Elsevier.

CA (2001). National Strategy for an Ageing Australia. An Older Australia, Challenges and Opportunities for All. Canberra, Australia: Department of Health and Ageing, Commonwealth of Australia. Retrieved from http://hdl.voced.edu.au/10707/79952.

CABE (2006). New Localism and Community Engagement: What It Means for Public Space Quality. London, UK: Commission for Architecture and the Built Environment.

CABE (2007). It's Our Space. A Guide for Community Groups Working to Improve Public Space. London, UK: Commission for Architecture and the Built Environment.

Calavita, N. \& Mallach, A. (2009). Inclusionary housing, incentives, and land value recapture. Land Lines, 21(1), 15-21. Retrieved from https://www.lincolninst.edu/sites/default/files/pubfiles/1552 777 Article\%203.pdf

Cattell, V.; Dines, N.; Gesler, W., \& Curtis, S. (2008). Mingling, observing, and lingering: everyday public spaces and their implications for well-being and social relations. Health \& Place, 14(3), 544-561. DOI: https://doi.org/10.1016/j.healthplace.2007.10.007 
Chao, T. Y. S. (2017). Planning for Greying Cities: Age-Friendly City Planning and Design Research and Practice. New York, USA: Routledge.

Chappell, N. L.; Havens. B.; Hollander, M. J.; Miller, J. A., \& McWilliam, C. (2004). Comparative costs of home care and residential care. The Gerontologist, 44, 389-400. DOI: https://doi.org/10.1093/geront/44.3.389

CLG (2008a). Improving Public Access to Better Quality Toilets. Wetherby, UK: Communities and Local Government Publications.

CLG (2008b). Lifetime Homes, Lifetime Neighbourhoods. A National Strategy for Housing in an Ageing Society. Wetherby, UK: Communities and Local Government Publications.

CLG, \& DFT (2007). Manual for Streets. London, UK: Communities and Local Government, Department for Transport, Thomas Telford Publishing.

Crook, T.; Monk, S.; Lister, D.; Lovatt, R.; Luanaigh, A.; Rowley, S., \& Whitehead, C. M. E. (2006). Delivering Affordable Housing through Section 106. York, UK: Joseph Rowntree Foundation.

Croucher, K. (2008). Housing Choices and Aspirations of Older People: Research from the New Horizons Programme. London, UK: Communities and Local Government. Retrieved from https://www.york.ac.uk/media/chp/documents/2008/newhorizonsolderpeople.pdf

Croucher, K., \& Myers, L. (2006). The Physical Characteristics of Urban Neighbourhoods and Health. Glasgow, UK: Centre for Population Health.

Croucher, K., \& Myers, L. (2008). The Health Impacts of Urban Green Spaces: A Literature Review. York, UK: Centre for Housing Policy, University of York.

Dalrymple, E. (2005). Livable Communities \& Aging in Place: Developing an Elder-Friendly Community. Washington DC. USA: Partners for Livable Communities \& National Association of Area Agencies on Aging.

Dawkins, C.; Jeon, J. S., \& Knaap, G. J. (2017). Creating and preserving affordable homeownership opportunities: does inclusionary zoning make sense? Journal of Planning Education and Research, 37(4), 444-456. DOI: https://doi.org/10.1177/0739456X16659763

De Jong Gierveld, J.; Fokkema, T., \& Van Tilburg, T. (2011). Alleviating loneliness among older adults. In Age UK. (Ed.), Safeguarding the Convoy: A Call to Action from the Campaign to End Loneliness (pp. 41-45). Oxon, UK: Age UK Oxfordshire.

Dellinger, A. M.; Sehgal, M.; Sleet, D. A., \& Barrett-Connor, E. (2001). Driving cessation: what older former drivers tell us. Journal of the American Geriatrics Society, 49(4), 431-435. DOI: https://doi.org/10.1046/j.1532-5415.2001.49087.x

Diez, A. (2003). The examination of neighbourhood effects on health: conceptual and methodological issues related to the presence of multiple levels of organization. In L. Berkman, \& I. Kawachi. (Eds.), Neighbourhoods and Health (pp. 45-64). New York, USA: Oxford University Press.

Ditmar, H., \& Ohland, G. (2004). The New Transit Town. Best Practices in Transit-Oriented Development. Washington DC., USA: Island Press. 
D'Onofrio, R., \& Trusiani, E. (2018). Urban Planning for Healthy European Cities. Cham, Switzerland: Springer.

Edwards, P., \& Tsouros, A. (2006). Promoting Physical Activity and Active Living in Urban Environments: The Role of Local Governments. Madrid, Spain: World Health Organization. Retrieved from https://www.euro.who.int/ data/assets/pdf file/0009/98424/E89498.pdf

Enssle, F., \& Kabisch, N. (2020). Urban green spaces for the social interaction, health and well-being of older people. An integrated view of urban ecosystem services and socio-environmental justice. Environmental Science \& Policy, $\quad 109, \quad 36-44 . \quad$ DOI: https://www.sciencedirect.com/science/article/pii/S1462901119310846?dgcid=author

Evans, G. W. (2003). The built environment and mental health. Journal of Urban Health-Bulletin of the New York Academy of Medicine, 80 (4), 536-555. DOI: https://doi.org/10.1093/jurban/jtg063

Evans, G. W.; Wells, N. M., \& Moch, A. (2003). Housing and mental health: a review of the evidence and a methodological and conceptual critique. Journal of Social Issues, 59(3), 475-500. DOI: https://doi.org/10.1111/1540-4560.00074

Falconer, K. (2001). The New Urbanism: where to and for whom? Investigation of an emergent paradigm. Urban Geography, 22, 202-19. DOI: https://doi.org/10.2747/0272-3638.22.3.202

Farr, D. (2008). Sustainable Urbanism. Urban Design with Nature. Hoboken, USA: John Wiley \& Sons. Feldman, P. H.; Oberlink, M.; Rudin, D.; Clay, J.; Edwards, B., \& Stafford, P. B. (2003). Best Practices: Lessons for Communities in Supporting the Health, Well-Being, and Independence of Older People. New York, USA: Center for Home Care Policy and Research, Visiting Nurse Service of New York.

Fisher, K. J., \& Li, F. Z. (2004). A community-based walking trial to improve neighborhood quality of life in older adults: a multilevel analysis. Annals of Behavioral Medicine, 28(3), 186-194. DOI: http://dx.doi.org/10.1207/s15324796abm2803 7

Fox, S.; Kenny, L.; Day, M. R.; O'Connell, C.; Finnerty, J., \& Timmons, S. (2017). Exploring the housing needs of older people in standard and sheltered social housing. Gerontology and Geriatric Medicine, 3, 1-14. DOI: https://doi.org/10.1177/2333721417702349

Garde, A. (2020). New Urbanism: Past, present, and future. Urban Planning, 5(4), 453-463. DOI: http://dx.doi.org/10.17645/up.v5i4.3478

Gaymu, J. (2003). The housing conditions of elderly people. Genus, 59(1), 201-226. Retrieved from https://www.jstor.org/stable/29788755

GLA (2006). Valuing Older People: The Mayor of London's Older People's Strategy. London, UK: Greater London Authority, the Mayor of London's Office.

Glicksman, A., \& Ring, L. (2017). Defining the goals of age-friendly interventions. Journal of Housing for the Elderly, 31(2), 93-98. DOI: https://doi.org/10.1080/02763893.2017.1309925

Godshalk, D. R. (2004). Land use planning challenges: coping with conflicts in visions of sustainable development and livable communities. Journal of the American Planning Association, 70(1), 5-13. DOI: $\underline{\text { https://doi.org/10.1080/01944360408976334 }}$

Grabowski, D. C. (2006). The cost-effectiveness of noninstitutional long-term care services: review and synthesis of the most recent evidence. Medical Care Research and Review, 63(1), 3-28. DOI: https://doi.org/10.1177/1077558705283120 
Grant, J. (2006). Planning the Good Community: New Urbanism in Theory and Practice. London, UK: Routledge.

Gren, A.; Colding, J.; Berghauser-Pont, M., \& Marcus, L. (2019). How smart is smart growth? Examining the environmental validation behind city compaction. Ambio, 48(6), 580-589. DOI: https://doi.org/10.1007/s13280-018-1087-y

Guterbock, T.; Kochera, A., \& Straight, A. (2005). Beyond 50.05. A Report to the Nation on Livable Communities: Creating Environments for Successful Aging. Washington DC., USA: American Association of Retired Persons Public Policy Institute. Retrieved from https://assets.aarp.org/rgcenter/il/beyond 50 communities.pdf

Handy, S. (2005). Smart growth and the transportation-Land use connection: What does the research tell us? International Regional Science Review, 28(2), 146-167. DOI: https://doi.org/10.1177\%2F0160017604273626

Handy, S. L.; Boarnet, M. G.; Ewing, R., \& Killingsworth, R. E. (2002). How the built environment affects physical activity: views from urban planning. American Journal of Preventive Medicine, 23(2), 64-73. DOI: https://doi.org/10.1016/S0749-3797(02)00475-0

Hanson, D. (2006). Assessing a community's elder friendliness. Family \& Community Health, 29(4), 266-278. https://doi.org/10.1097/00003727-200610000-00005

Harding, E. D. (2007). Towards Lifetime Neighbourhoods: Designing Sustainable Communities for All. London, UK: International Longevity Centre UK, Department for Communities and Local Government. Retrieved from https://ilcuk.org.uk/wpcontent/uploads/2018/10/TowardsLifetimeNeighbourhoods.pdf

Harrell, R.; Brooks, A., \& Nedwick, T. (2009). Preserving Affordability and Access in Livable Communities: Subsidized Housing Opportunities Near Transit and the 50+ Population. Washington DC., USA: American Association of Retired Persons Public Policy Institute. Retrieved from http://assets.aarp.org/rgcenter/ppi/liv-com/2009-15.pdf

Harrison, L., \& Heywood, F. (2000). Health Begins at Home: Planning at the Health-Housing Interface for Older People. Bristol, UK: Policy Press.

Harvison, T.; Newman, R., \& Judd, B. (2011). Ageing, the Built Environment and Adaptation to Climate Change. Sydney, Australia: City Futures Research Centre, Faculty of Built Environment, University of New South Wales.

Heywood, F. (2004). The health outcomes of housing adaptations. Disability \& Society, 19(2), 129-143.

Heywood, F.; Oldman, C., \& Means, R. (2001). Housing and Home in Later Life. Buckingham, UK: Open University Press.

HM Government (2006). Independence and Well-Being of Older People: Baseline Report, a Social Portrait of Ageing in the UK. London, UK: Corporate Document Services.

Hockey, A.; Philips, J., \& Walford, N. (2013). Planning for an ageing society: voices from the planning profession. Planning Practice and Research, 28(5), 527-543. DOI: https://doi.org/10.1080/02697459.2013.820039 
Holland, C.; Clark. A.; Katz, J., \& Peace, S. (2007). Social Interactions in Urban Public Places. Bristol, UK: The Policy Press.

Howe, D. (2001). Aging and Smart Growth: Building Aging-Sensitive Communities. Miami, USA: Funders' Network for Smart Growth and Livable Communities, Collins Center for Public Policy.

Jones, P.; Roberts, M., \& Morris, L. (2007). Rediscovering Mixed-Use Streets: The Contribution of Local High Streets to Sustainable Communities. Bristol, UK: The Policy Press.

Kalache, A., \& Plouffe, L. (2010). Towards global age-friendly cities: determining urban features that promote active aging. Journal of Urban Health, 87(5), 733-739. DOI: https://doi.org/10.1007/s11524$\underline{010-9466-0}$

Kaplan, R. (2001). The nature of the view from home-psychological benefits. Environment and Behaviour, 33(4), 507-542. DOI: https://doi.org/10.1177/00139160121973115

Keating, N., \& Scharf, T. (2012). From Exclusion to Inclusion in Old Age: A Global Challenge. Bristol, UK: Policy Press.

Kellaher, L.; Peace, S., \& Holland, C. (2004). Environment, identity and old age - quality of life or a life of quality. In C. Hennessy, \& A. C. Walker. (Eds.), Growing Older: Quality of Life in Old Age (pp. 6080). Maidenhead, UK: Open University Press.

Kemperman, A.; van den Berg, P.; Weijs-Perrée, M., \& Uijtdewillegen. K. (2019) Loneliness of Older Adults: Social Network and the Living Environment. International Journal of Environmental Research and Public Health, 16(3), 406. DOI: https://doi.org/10.3390/ijerph16030406

Kendig, H. (2003). Directions in environmental gerontology: a multidisciplinary field. The Gerontologist, 43, 611-614. DOI: https://doi.org/10.1093/geront/43.5.611

Kenworthy, J. R. (2006). The eco-city: ten key transport and planning dimensions for sustainable city development. Environment and Urbanization, 18(1), 67-85. DOI: https://doi.org/10.1177/0956247806063947

Korpela, K. M., \& Ylen, M. (2007). Perceived health is associated with visiting natural favourite places in the vicinity. Health \& Place, 13(1), 138-151. DOI: https://doi.org/10.1016/j.healthplace.2005.11.002

Lawton, M. P. (1982). Competence, environmental press, and the adaptation of older people. In T. O. Byerts; M. P. Lawton, \& P. G. Windley. (Eds.), Aging and the Environment: Theoretical Approaches (pp. 33-59). New York, USA: Springer Publishing Company.

Lawton, M. P., \& Nahemow, L. (1973). Ecology and the aging process. In C. Eisdorfer, \& M. P. Lawton. (Eds.), The Psychology of Adult Development and Aging (pp. 619-674). Washington DC, USA: American Psychological Association.

Li, Y.; Hsu, J. A., \& Fernie, G. (2013). Aging and the use of pedestrian facilities in winter-the need for improved design and better technology. Journal of Urban Health, 90(4), 602-617. DOI: https://doi.org/10.1007/s11524-012-9779-2

Littleford, A., \& Kralik, D. (2010). Making a difference through integrated community care for older people. Journal of Nursing and Healthcare of Chronic Illness, 2(3), 178-186. DOI: https://doi.org/10.1111/j.1752-9824.2010.01061.x 
Lui, C. W.; Everingham, J. A.; Warburton, J.; Cuthill, M., \& Bartlett, H. (2009). What makes a community age-friendly: a review of international literature. Australasian Journal on Ageing, 28(3), 116-121. DOI: https://doi.org/10.1111/j.1741-6612.2009.00355.x

Manchester City Council (2004). Towards a Quality of Life Strategy for Manchester's Older People. Manchester, UK: Manchester City Council.

Manchester City Council (2009). Manchester: A Great Place to Grow Older 2010-2020. Manchester, UK: Manchester City Council.

Mehdipanah, R.; Eisenberg, A. K., \& Schulz, A. (2019). Housing. In S. Galea; C. K. Ettman, \& D. Vlahov. (Eds.), Urban Health (pp. 44-51) New York, USA: Oxford University Press.

Menec, V.; Means, R.; Keating, N.; Parkhurst, G., \& Eales, J. (2011). Conceptualizing age-friendly communities. Canadian Journal on Aging, 30(3), 479-493. DOI: https://doi.org/10.1017/S0714980811000237

Menec, V., \& Brown, C. (2018). Facilitators and barriers to becoming age-friendly: A review. Journal of Aging \& Social Policy, 1-23. DOI: https://doi.org/10.1080/08959420.2018.1528116

Michael, Y. L.; Green, M. K., \& Farquhar, S. A. (2006). Neighborhood design and active aging. Health \& Place, 12(4), 734-740. DOI: https://doi.org/10.1016/j.healthplace.2005.08.002

NAAA (2011). The Maturing America: Communities Moving Forward for an Aging Population. Washington DC., USA: National Association of Area Agencies on Aging. Retrieved from https://www.n4a.org/files/Maturing of Ameria Ll.pdf

NAAA, \& PFLC (2007). A Blueprint for Action: Developing a Livable Community for All Ages. Washington DC., USA: National Association of Area Agencies on Aging, and Partners for Livable Communities. Retrieved from http://livable.org/storage/documents/reports/AIP/blueprint4actionsinglepages.pdf

NCC, \& NU (2009). Creating Older Person Friendly Neighbourhoods, Cowgate. Newcastle, UK: Newcastle City Council and Newcastle University.

Newton, R.; Ormerod, M.; Burton, E.; Mitchell, L., \& Ward-Thompson, C. (2010). Increasing independence for older people through good street design. Journal of Integrated Care, 18(3), 24-29. DOI: https://doi.org/10.5042/jic.2010.0246

NSWG (2001). Integrating Land Use and Transport. Improving Transport Choice, Guidelines for Planning and Development. Sydney, Australia: Department of Infrastructure, Planning and Natural Resources, New South Wales Government.

NSWG (2004). Planning Guidelines for Walking and Cycling. Sydney, Australia: Department of Infrastructure, Planning and Natural Resources, New South Wales Government.

Oberlink, M. R. (2008). Opportunities for Creating Livable Communities. Washington DC., USA: American Association of Retired Persons Public Policy Institute, Center for Home Care Policy and Research. Retrieved from https://aging.ny.gov/system/files/documents/2020/03/2008 02 communities.pdf

OECD (2003). Ageing, Housing and Urban Development. Paris, France: Organisation for Economic CoOperation and Development Publications. 
Oka, K., \& Koohsari, M. J. (Eds.) (2020). Walkable Neighborhoods: The Link between Public Health, Urban Design, and Transportation. Basel, Switzerland: MDPI Books. DOI: https://doi.org/10.3390/books978-3-03921-931-5

PAFA (2002). The Age Friendly Guidelines Project. Cottesloe, Australia: Positive Ageing Foundation of Australia.

Peace, S. M.; Holland, C., \& Kellaher, L. (2005). Making space for identity, policy, practice. In G. J. Andrews, \& D. R. Phillips. (Eds.), Ageing and place: Perspectives, Policy, Practice (pp. 188-204). New York, USA: Routledge.

Phillips, D. R.; Liu, L.; Yeh, A. G., \& Cheng, K. H. (2005). Ageing and the urban environment. In G. J. Andrews, \& D. R. Phillips. (Eds.), Ageing and place: Perspectives, Policy, Practice (pp. 147-163). New York, USA: Routledge.

Phillipson, C. (2004). Urbanisation and ageing: towards a new environmental gerontology. Ageing and Society, 24(6), 963-972. DOI: https://doi.org/10.1017/S0144686X04002405

Phillipson, C. (2007). The 'elected' and the 'excluded': sociological perspectives on the experience of place and community in old age. Ageing and Society, 27(3), 321-342. DOI: https://doi.org/10.1017/S0144686X06005629

Phillipson, C. (2011). Developing age-friendly communities: new approaches to growing old in urban environment. In J. L. Angel, \& R. Settersten. (Eds.), Handbook of the Sociology of Aging (pp. 279-293). New York, USA: Springer Publishing Company.

Pynoos, J., \& Nishita, C. M. (2007). Aging in place. In S. Carmel, C. A. Morse, \& F. M. Torres. (Eds.), Lessons on Aging from Three Nations: The Art of Aging (pp. 185-198). New York, USA: Baywood.

Rantanen, T.; Portegijs, E.; Viljanen, A.; Eronen, J.; Saajanaho, M.; Tsai, L. T.; Kauppinen, M.; Palonen, E. M.; Sipilä, S.; Iwarsson, S., \& Rantakokko, M. (2012). Individual and environmental factors underlying life space of older people - study protocol and design of a cohort study on life-space mobility in old age (LISPE). BMC Public Health, 12. DOI: https://doi.org/10.1186/1471-2458-12-1018

Rosenbloom, S. (2004). Mobility of the elderly: good news and bad news. In J. Weeks, \& N. Solomon. (Eds.), Transportation in an Aging Society: A Decade of Experience (pp. 3-12). Washington DC., USA: Transportation Research Board.

Rosenbloom, S., \& Winsten-Bartlett, C. (2002). Asking the right question: understanding the travel needs of older women who do not drive. Journal of the Transportation Research Board, 1818(1), 7882. DOI: https://doi.org/10.3141/1818-12

Saelens, B. E.; Sallis, J. F., \& Frank, L. D. (2003). Environmental correlates of walking and cycling: findings from the transportation, urban design, and planning literatures. Annals of Behavioural Medicine, 25, 80-91. DOI: https://doi.org/10.1207/S15324796ABM2502 03

Salat, S. (2011). Cities and Forms: On Sustainable Urbanism. Paris, France: Hermann Editeurs.

Salomon, E. (2006). Older residents can become smart growth advocates. Public Management, 88(8), 18-22. 
Scharf, T., \& Smith, A. E. (2004). Older people in urban neighbourhoods: Addressing the risk of social exclusion in later life. In G. Allan, D. Morgan, \& C. Phillipson. (Eds.), Social Networks and Social Exclusion: Sociological and Policy Perspectives (pp. 162-179). Aldershot, UK: Ashgate.

Shrestha, B. P.; Millonig, A.; Hounsell, N. B., \& McDonald, M. (2017). Review of public transport needs of older people in European context. Journal of population ageing, 10(4), 343-361. DOI: https://doi.org/10.1007/s12062-016-9168-9

Slone, D. K.; Goldstein, D. S., \& Gowder, W. A. (2008). A Legal Guide to Urban and Sustainable Development for Planners, Developers, and Architects. Hoboken, USA: John Wiley \& Sons, Inc.

Smith, A. E. (2009). Ageing in Urban Neighbourhoods. Place Attachment and Social Exclusion. Bristol, UK: The Policy Press.

Snell, C., \& Jones, P. (2007). Accessibility Problems in the Dearne: Experiences of Some Local Residents and Their Suggestions for Solutions. A Case Study for Developing Accessibility Planning Tools for Problem Identification and Option Generation. DISTILLATE Working Paper. London, UK: Centre for Transport Studies, University College London.

Steels, S. (2015). Key characteristics of age-friendly cities and communities: A review. Cities, 47, 4552. DOI: https://doi.org/10.1016/j.cities.2015.02.004

Sugiyama, T., \& Thompson, C. W. (2007). Outdoor environments, activity and the well-being of older people: conceptualising environmental support. Environment and Planning A, 39(8), 1943-1960. DOI: https://doi.org/10.1068/a38226

Sugiyama, T.; Thompson, C.W., \& Alves, S. (2009). Associations between neighborhood open space attributes and quality of life for older people in Britain. Environment and Behaviour, 41(1), 3-21. DOI: https://doi.org/10.1177/0013916507311688

Sumner, K. (2002). Our Homes, Our Lives. Choice in Later Life Living Arrangements. London, UK: Centre for Policy on Ageing, the Housing Corporation.

Sun, Y.; Ng, M. K., \& Chao, T. S. (2020). Age-friendly urbanism: intertwining 'ageing in place' and 'place in ageing'. Town Planning Review, 91(6), 601-621. DOI: https://doi.org/10.3828/tpr.2020.87

Talen, E. (2005). New Urbanism and American Planning: The Conflict of Cultures. New York, USA: Routledge.

Thompson, H.; Petticrew, M., \& Morrison, D. (2002). Housing Improvement and Health Gain: A Summary and Systematic Review. Glasgow, UK: Medical Research Council, Social \& Public Health Sciences Unit.

Tucker, P. (2005). Mobility for tomorrow's seniors - public transit must plan now to meet the needs of an aging population. Futurist, 39(6), 10-11.

US EPA (2009). Growing Smarter, Living Healthier. A Guide to Smart Growth and Active Aging. Washington DC., USA: US Environmental Protection Agency, Office of Children's Health Protection and Environmental Education, and the Child and Aging Health Protection Division.

Van den Berg, A. E.; Hartig, T., \& Staats, H. (2007). Preference for nature in urbanized societies: stress, restoration, and the pursuit of sustainability. Journal of Social Issues, 63(1), 79-96. DOI: https://doi.org/10.1111/j.1540-4560.2007.00497.x 
WA Planning Commission (2000). Introducing Liveable Neigbourhoods. Perth, Australia: Western Australia Planning Commission.

Wahl, H. W., \& Lang, F. (2003). Ageing in context across the adult life course: integrating physical and social environmental research perspectives. In R. Scheidt, H.W. Wahl, \& P. G. Windley. (Eds.), Ageing in Context: Socio-Physical Environments (pp. 1-34). New York, USA: Springer Publishing Company.

Walker, A. (2005). Quality of life in old age in Europe. In A. Walker. (Ed.), Growing Older in Europe (pp. 1-13). Suffolk, UK: Open University Press.

Warner, M. E., \& Zhang, X. (2019). Planning communities for all ages. Journal of Planning Education and Research. DOI: https://doi.org/10.1177/0739456X19828058

Waters, J.; Neale, R., \& Mears, K. (2008). Design and Community Regeneration: Older People in SocioEconomically Deprived Communities in South Wales. Pontypridd, UK: University of Glamorgan.

Weil, J., \& Smith, E. (2016). Revaluating aging in place: from traditional definitions to the continuum of care. Working with Older People, 20(4), 223-230. DOI: https://doi.org/10.1108/WWOP-08-2016-0020

Whitehead, C. M. E. (2007). Planning policies and affordable housing: England as a successful case study? Housing Studies, 22(1), 25-44. DOI: https://doi.org/10.1080/02673030601024580

WHO (2002). Active Ageing: A Policy Framework. Geneva, Switzerland: World Health Organisation. Retrieved from https://www.who.int/ageing/publications/active ageing/en/

WHO (2007a). Global Age-friendly Cities: A Guide. Geneva, Switzerland: World Health Organisation. Retrieved from

https://www.who.int/ageing/publications/Global age friendly cities Guide English.pdf

WHO (2007b). Checklist of Essential Features of Age-Friendly Cities. World Health Organisation. Retrieved from http://www.who.int/ageing/publications/Age friendly cities checklist.pdf

WHO (2019). Global action plan on physical activity 2018-2030: more active people for a healthier world. World Health Organization. Retrieved from https://www.who.int/ncds/prevention/physicalactivity/global-action-plan-2018-2030/en/

Wiles, J.; Leibing, A.; Guberman, N.; Reeve, J., \& Allen, R. (2011). The meaning of 'ageing in place' to older people. The Gerontologist, 51(5), 1-10. DOI: https://doi.org/10.1093/geront/gnr098

Windle, G. S.; Burholt, V., \& Edwards, R. T. (2006). Housing related difficulties, housing tenure and variations in health status: evidence from older people in Wales. Health \& Place, 12(3), 267-278. DOI: https://doi.org/10.1016/j.healthplace.2004.08.010

Wong, C.; Wong, S.; Pang, W.; Azizah, M., \& Dass, M. (2003). Habitual walking and its correlation to better physical function: implications for prevention of physical disability in older persons. Journals of Gerontology Series A: Biological and Medical Sciences, 58(6), 555-560. DOI: https://doi.org/10.1093/gerona/58.6.M555 